\title{
O que fazer com os conteúdos?... uma análise
}

An analysis of what can be done about content

¿¿ué hacer con los contenidos?... un análisis

Moisés Goldbaum ${ }^{1}$

O texto do Prof. José Castilho Marques Neto aborda um assunto relevante e atual, seja da perspectiva da difusão e divulgação de conhecimentos, seja do ângulo da avaliação do conhecimento e de sua interpretação por agências de fomento.

Embora entenda que a encomenda que me foi feita deva dirigir-se mais à segunda das intenções, aproveito para tecer algumas considerações sobre a primeira. Assim, não há como discordar de sua análise das revolucionárias formas e tecnologias de difusão disponíveis para fazer frente a esta "nova abundância" de informações e conhecimentos existentes e produzidos, enfatizando-se a produção expressa em livros. Até onde me é permitido avançar, pode-se afirmar que, do ponto de vista de exposição destes novos e infinitos produtos, a eletrônica deu um passo enorme e praticamente os coloca "just on time" e "on line" à disposição dos potenciais usuários. A questão que surge refere-se a como fazer a triagem desse amplo (quase infinito) conjunto de informações geradas e como depurá-las ou como sobre elas debruçar-se. O autor fornece uma pista: a garantia da qualidade do conteúdo, e para tanto faz-se valer dos parâmetros da CAPES como um dos instrumentos. Entretanto, se não houver um elemento indicador desses parâmetros, caberá a cada um dos "acessadores" dos materiais fazer seu próprio julgamento da qualidade, o que não se mostra algo plausível ou incorporável. Mas o autor segue na pista e indica o comportamento de sua Universidade, a UNESP, na qual se concebeu "uma Editora Universitária que se pauta essencialmente pela avaliação e gerenciamento de conteúdos ...". Concordando com sua posição, mesmo porque temos que reconhecer a competência e seriedade da Editora da UNESP, encontramos o instrumento para a certificação da qualidade dos trabalhos. Trata-se, então de buscar a legitimação das Editoras que cumprem fielmente seu papel de atender os critérios de qualidade definidos peço conjunto da comunidade técnico-científica, que se encontra majoritariamente localizada nas nossas Universidades e Institutos de Pesquisa.

\footnotetext{
${ }^{1}$ Secretário de Ciência, Tecnologia e Insumos Estratégicos, Ministério da Saúde, Brasília, DF.; Professor, Departamento de Medicina Preventiva, Faculdade de Medicina, Universidade de São Paulo (FMUSP). <mgoldbau@usp.br>
} 


\section{DEBATES}

As dificuldades impostas pela comercialização de livros, especialmente daqueles que se destinam a um conjunto pequeno de interessados (menos de mil), como aponta 0 Prof. Marques Neto, devem ser consideradas? Penso, como ele, que sim. Entretanto, fica a indagação se estes casos constituem situações muito comuns e para que áreas esta situação mostrar-se-ia adequada. Lembro que a forma de diálogo editorial dos diferentes campos disciplinares varia substancialmente. Algumas áreas dialogam mais freqüentemente por intermédio de periódicos, cuja qualidade editorial varia também significativamente. Este é um dos elementos que parece justo salientar, para indicar que o debate deve ser aprofundado e explorado em todos os seus níveis, cabendo explicitar suas "regras" e parâmetros, atendidas as especificidades das diferentes áreas. Nesta situação, penso que podemos aprimorar e ampliar o acesso qualificado a essas publicações.

Quanto à segunda perspectiva, cabe-me acrescentar algumas observações que merecem a devida atenção. Antes, porém, é necessário destacar que os sistemas de avaliação de nossas agências, e como bem reconhece o autor, o da CAPES, "para as pósgraduações brasileiras que constitui proposta avançada, complexa e em constante redefinição", é um trabalho da própria comunidade científica (e não da agência, que cria as condições para tanto - quero aqui reiterar que não a estou defendendo de suas eventuais deficiências). É ela, comunidade, que elabora os critérios, cuja "transparência", ou melhor, visibilidade é inquestionável e, assim, é dela e com ela (comunidade científica) no seu todo que eles (critérios) devem ser analisados e debatidos.

A defesa que a autor faz do primado da qualidade do conteúdo é a sua própria resposta à sugestão do "manejo adequado dos conteúdos". Assim, é necessário que se explicite o que se considera como "generosidade e compreensão" na análise dos livros. Se isto implica atender a visibilidade dos critérios, o atendimento da qualidade e a certificação e auditagem das editoras, concordo plenamente e nada teria a acrescentar, respeitado, obviamente, aquilo que ensaiei na análise das especificidades. Caso contrário, se implica a incorporação de vantagens ditadas pela necessidade de atender a produção pela produção (que estou certo não é o que o autor está propondo) temos de rever o debate apresentado.

Por fim, saliento que o texto do Prof. Marques Neto se destaca por apresentar um tema polêmico que merece o devido aprofundamento e, que suponho, teve seus desdobramentos no Simpósio aludido. Sua divulgação deve ser feita para que a comunidade possa incorporar os elementos para aprimorar o processo de avaliação que, por mais que queiramos, nunca emprestará a total satisfação de todos os envolvidos, até porque a avaliação sempre deve implicar um instrumento de estímulo à progressão (e não um caráter punitivo) e, portanto, sempre terá um poder discriminante.

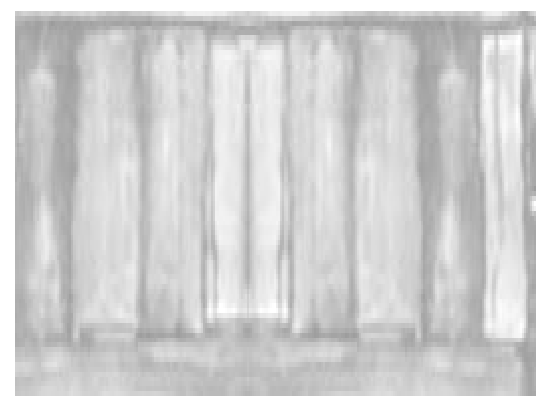

